\title{
インターネットを利用した宏観異常情報システムの機能強化と運用 Functional strengthening and employment of Macroscopic Anomaly System by e-PISCO ASP
} 和佐 好智* 弘原海 清**

\author{
Yoshitomo WASA and Kiyoshi WADATUMI
}

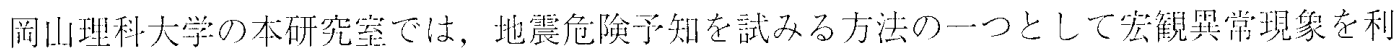
用している。答钼翼常現象は，大地震発生前に震源地周辽で多く認められる自然や動物の買 常のことである。この宏観異常現俰を利用して地震危除予知を行うためには，より迅速な収 集・公開システムが必要である。このため，砳究窒のWeb サイト (e-PISCO) たでインター ネットを使った宏観異常情報の収集・公開を2000 年9月15日より開始した。この収集・公 開を可能にしたシステムが空観買常情報システムである。この丢観異常情報システムの㙨能 強化の内容と，2002 年 12 月までの運用結果老紹介する。
\end{abstract}

We use Macroscopic Anomaly as one of the methods of trying earthquake prediction at this laboratory of Okayama University of Science. Generally, Macroscopic Anomaly just before the occurrence of an earthquake is observed in the circumference of the focus. In order to use this macroscopic anomaly and to perform an earthquake prediction, a quicker collection and public presentation system is required. For this reason, MASPA (Macroscopic Anomaly System by e-PISCO ASP) were started from September, 2000 on the website of a laboratory. Functional strengthening of MASPA and the employment result by December, 2002 is introduced.

キーワード：宏観兴常，地震予知，インターネット，MASPA，

Macroscopic Anomaly, Earthquake prediction, Internet

\section{1 はじめに}

宏観異常現象は大地震の前に発生すること が知られている。岡山理科大学弘原海研究室 ではこの宏観異常現象の情報 (宏観異常情報) を収集・公開し，地震危険予知に利用しよう としている，宏観異常現象とは，地震の発生 前に起きる動物や大気，電子機器などの異常

* 岡山理科大学大学院 総合情報学部 生物地球システム 専攻

Department of Biosphere-Geosphere System Science, Graduate School of Informatics, Okayama University of Science

E-mail:number9@pisco.ous.ac.jp

**岡川理科大学 総合情報学部生物地球システム学科

Department of Biosphere-Geosphere System Science, Faculty of Informatics, Okayama University of Science

E-mail:wadatumi@big.ous.ac.jp
現象を指寸言葉である。中国語で「宏観異常 現象」と呼んでいることから，日本語として も同じように宏観(こうかん) 異常現象と呼ん

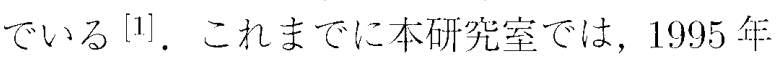
の兵庫県南部地震や 1999 年の台湾中部地震な ど，多くの現象情報を地震発生後に収集して きた。これをもとに，宏観異常現象について の情報分析が抢こなわれ，ある程度その傾向を

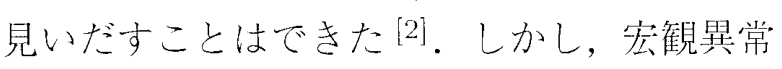
情報老地震前に大量に集めるのは困難であり, デー夕活用するまでに峙ってなかった。 そ れは，これまでの収集方法が主に電話やファッ クス,アンケート調查によるもので, 収集した 情報を公開するまでには多大な労力と時間が 必要であったためである。そこでこれらの問 題老解消するため，インターネットを利用し た宏観異常情報システムの開発を行った ${ }^{[3]}$. 
この宏観異常情報システム (Macroscopic Anomaly System by e-PISCO ASP) は, 2000 年 9 月 15 日上り本研究室の Web サ イト e-PISCO(http://www.pisco.ous.ac.jp/) 上で公開している。さらに，2001 年5月1 日からはモバイル用Webサイト i-PISCO (ht.tp://i.pisco.ous.ac.jp/) 孝構築し, 宏観異 常情報システムをNTTドコモの i-modeサ一 ビスへ対応，同作12月29日には.J-Phoneの J-Sky サービスへ対応し, 2002 年 6 月 9 日には auのEZwebサービスへの対応を実現した ${ }^{[4]}$. この宏観筫常情報システムの機能強化と2002 年度現在までの運用結果について紹介する。

\section{2 宏観異常情報システムの概要}

宏観異常情報システムは地震危険予知を目 的とし，宏観異常情報をインターネット上で收 集・公開するシステムである。宏観異常情報 システムの機能は, 宏観異常情報の収集と公開 の二つに分けることができる(図 1)。まず，左 観暴常情報の収集について説明する。PISCO
のWebサイトへ訪れた一般の閲覧者が㕕観異 常情報を送信するには，市民メンバー(宏観異 常現象のモニター)としての登録老行わなけ ればならない。市民メンバーとは，PISCOの 目指古住民参加型の地震危険予知に協力して くれる礼である。市民メンバー登録を行う ことにより，宏観異常情報の情報源を明確に し，メンバーそれぞれの情報を個別に管理で きる。こ机により情報の貿の问上が期待でき る。登録したメールアドレスとパスワードを 使用しログインすると，宏観異常情報の送信 や市民メンバー用揭示板への書き込みが可能 となる。次に，収集された情報の公開につい て説明京る。宏観罳常情報は, PISCOのWeb サイトを訪れたすべての者が閲覧可能である。 当初，閲覧厅法は収集した情報を表形式にし てすべて表示，都道府県ごとによる表示，厷 観異常の種類ごとに表示の三種類を用意して いた。

宏観暴常情報システムでは,デー夕ベースと 連携した動的なWebページにより，宏観異常 情報の自動収集・公開を実現している。これら

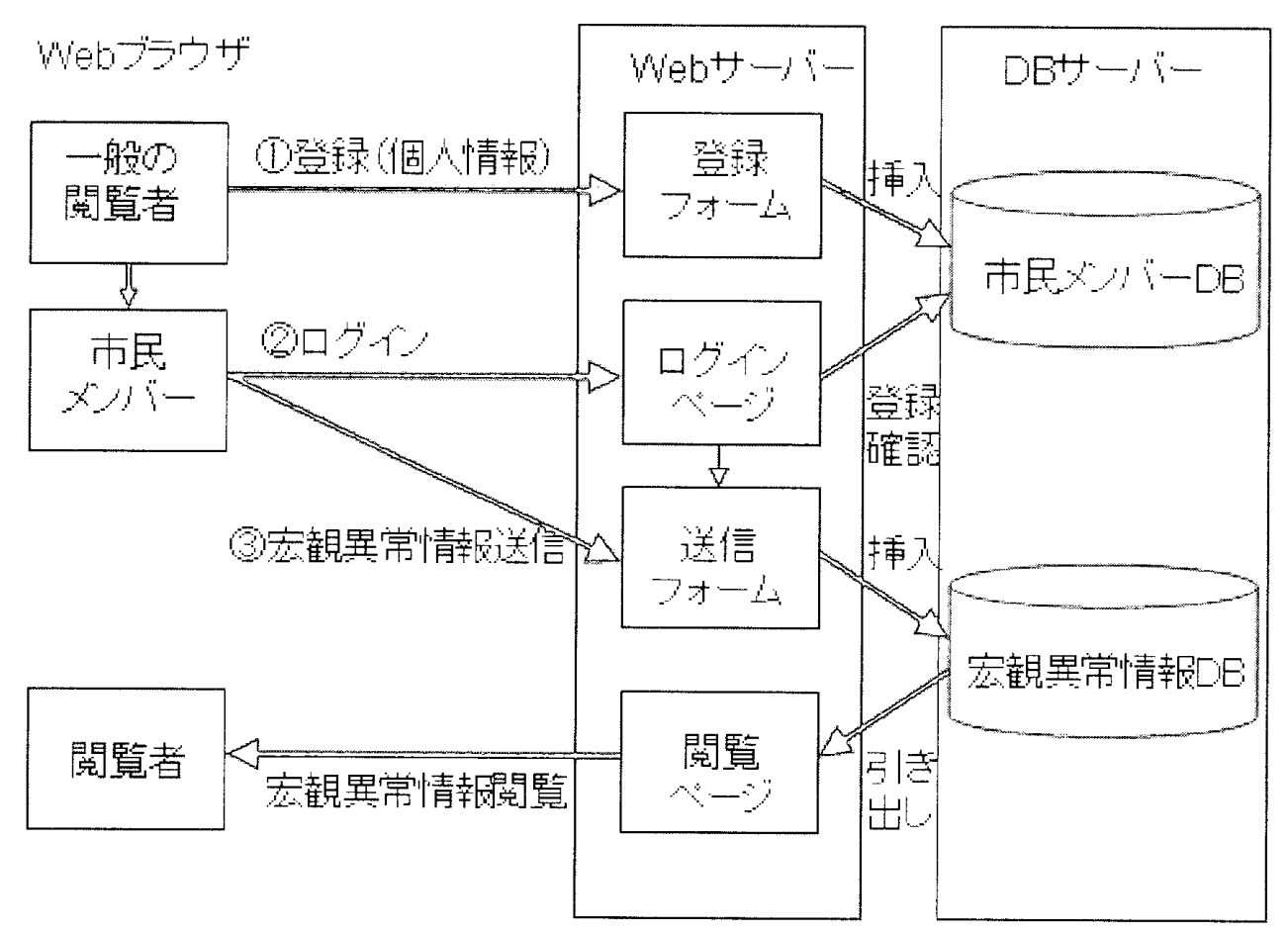

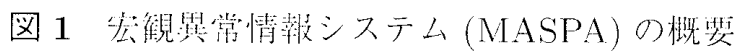


の動的な Webページは, ASP(Active Server Pages) を利用して作り出している. ASPは, Microsoft $の$ WebサーバーであるIIS(Internet Information Server) 上で動作するサーバーサ イドスクリプト環境である。ASPはサーバー サイドで動作するため，クライアント環境に 依存することなく, 動的な Webページを作成 することができる。

\section{3 宏観異常情報システムの強化}

\section{1 システムのソフトとハードの強 化}

宏観異常情報システムを開発した際に使用 したデータベースソフトは, Microsoft Access である. Microsoft Access は簡易型のデータ ベースソフトである。しかし，宏観異常情報シ ステムで蓄積していくデータはインターネッ ト上での収集・公開を目的としたものである ため，データベースソフトには安定で尚かつ正 確な動作が求められる。 Microsoft Accessは 蓄積可能なレコード数と同時アクセス数に限 界があり，基本的にはクライアント用ソフトで あるため，データベースサーバー用途には向い ていない．以上のことから，データベースソ フトにはデータベースサーバー用のソフトを 導入する必要があると考えた。そこで，デー タベースソフトには SQLServer 2000 を採用 した。これは，SQLServer 2000 がWindows 2000 Server と同じ Microsoft 製品であるため OS との親和性が高く，比較的扱いゃすいソ フトだからである。さらに，データベースソ フトの導入に伴いハードの強化も同時に行っ た。以前は一台の PCでWebサーバーとデー タベースを動作させていたが，これでは同時 アクセス数が増加した際にPCにかかる負荷 が高くなり，システムがダウンする危険性が あると考えたからである。また，情報が集積 されているデータベースはインターネット七 キュリテイの観点から，インターネット上に 公開されているWebサーバーと切り離したほ
うが安全であると考えた。このためサーバー 用 PC を一台追加し, Webサーバーとデー夕 ベースサーバーをそれぞれ一台の PCに分け て動作させることを考案し実用化した。

\section{2 システムのセキュリティの強化}

今回行ったセキュリテイ刘策は二種類ある. 一つは，市民メンバー登録などの際インター ネット上を流れる個人情報を守るためのもので ある。この問題は, SSL (Secure Socket Layer) を利用し，インターネット上を流れるデータ を暗号化することにより解決させた。もう一 つは，ネットワークサーバーを不正アクセスや ウィルスから守るためのセキュリティ対策で ある。本研究室の PISCO ドメインは一階層 上にある岡山理科大学トップサーバーのファ イヤーウォールで守られており，外部からのア クセスには制限がかけられている。しかし，学 内からの不正アクセスや, 正規ルート (WWW や Mail)によるウィルス感染対策が必要であ ると考えた。不正アクセス対策として，サー バー上で不要なサービスを停止させる，七キュ リティホールの確認されたソフトを使用しな い，OS・ソフトのアップデートを頻繁に行い 最新の状態を保つ, 強固なパスワードを設定す るなどを行っている。また，ウィルス感染に対 する対策として，研究室のすべての Windows パソコンにウィルス対策ソフトをインストー ルし，定期的にウイルスをスキャンするよう にしている。上記のようなセキュリティ対策 を行い，さらに，定期的にデータのバックアッ プを行うことによりデー夕損失などの非常時 対策も行っている。

\section{3 宏観異常情報表現方法の強化}

宏観異常情報の表現方法は当初，収集した 情報を表形式にしてすべて表示, 都道府県ご とに表示，異常の種類ごとに表示の三種類で あった。しかし，複雑な情報である宏観異常 情報を多面的に捉之，地震危険予知へ役立て 


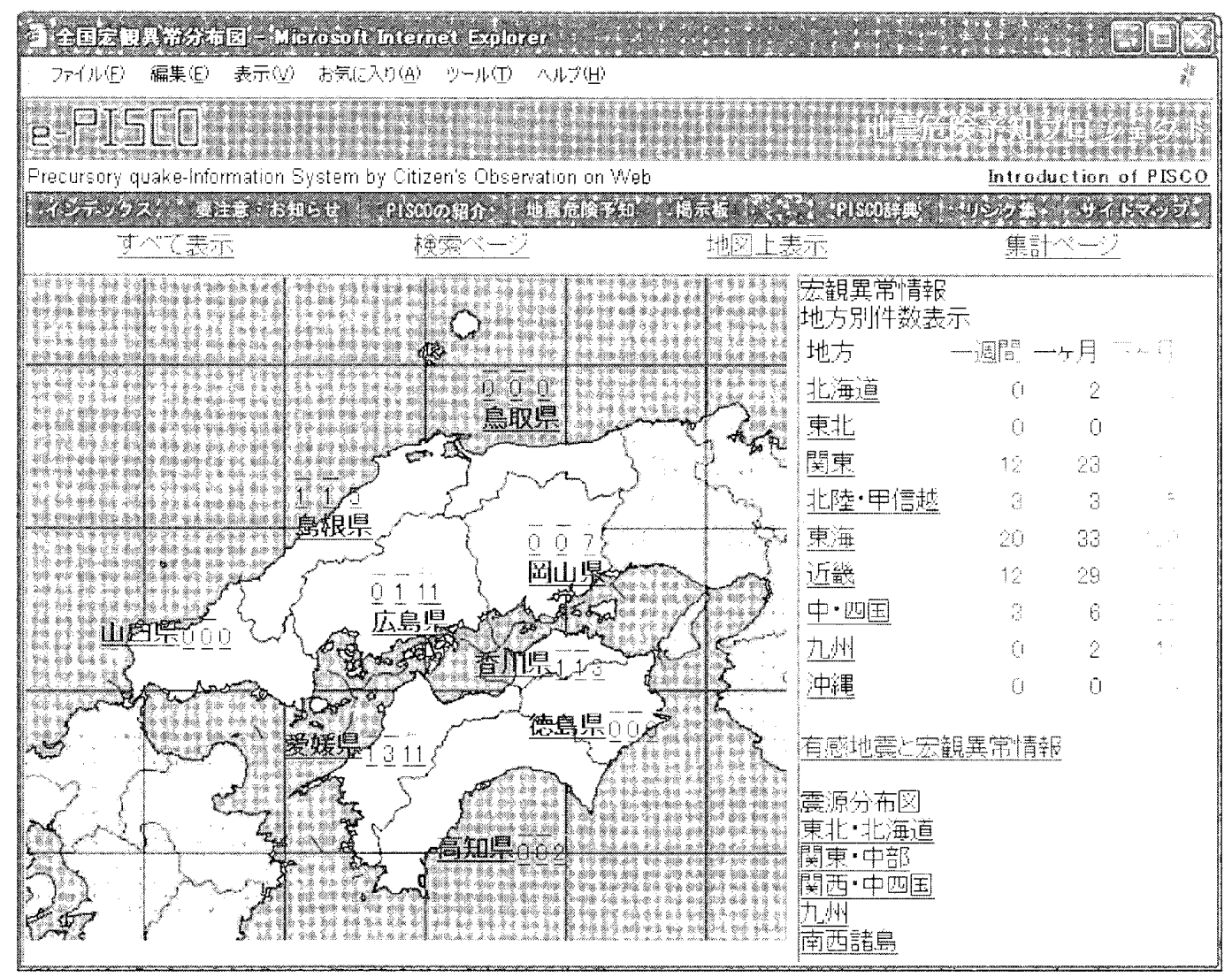

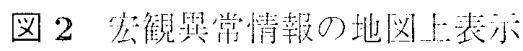

(http://www 1.pisco.ous.ac.jp/maspa/view/gis/gis_koukan.html)

るためには，よりわかりやすい表現方法が必 要であると考えた。そこで，情報を整理し，特 徵を考慮してからページを追加・改良するこ とにした。宏観異常情報は大きく分けて，時 間, 場所, 内容の三種類の要素で構成されて いる。この三種類の要素を二つ以上組み合わ せることにより，情報の絞迟みが行える。実 際に作成したページは以下の通りである。

○地図上で都道府県ごとの一定期間の情報 件数老表示 (時間, 場所)(四 2)

○都道府県ごとの)異常の種類別件数表示 (場 所, 内容)

○観察曰時, 都道府県，異常の種類の組み 合わせによる娭索 (時間, 場所, 内容)

○キーワード検索 (複数内容)

キーワード娭索は，キーワードを複数入力す ることにより情報の絞达みが行える。さらに， 以下のような情報件数集計ページを作成した。
○情報を異常の種類ごとに集計し円グラフ で表示(四 3)

○日単位の情報件数を溙㐌ラフで表示

○都道府県ごとの市民メンバー数とこれま で寄せられた情報件数表示

これに加え，宏観異常現象と実際の地震と の関連性を倹証するため，宏観買常情報件数 と有感地震老地図上に同時表示可能なページ (図 4)在開発した ${ }^{[5]}$ 。これは，最近 1 週閂の 地域別宏钼異常情報の件数と有感地震老地図 上にプロットしたもので，こ机を見れば視覚 的に画者の比較ができ丢観異常情報の検証を 篗易にすることができるようになった。この ページは, ASP と同時にSVG(Scalable Vector Graphics）を利用子ることにより，地図上に 地震をプロットすることを可能にした。 


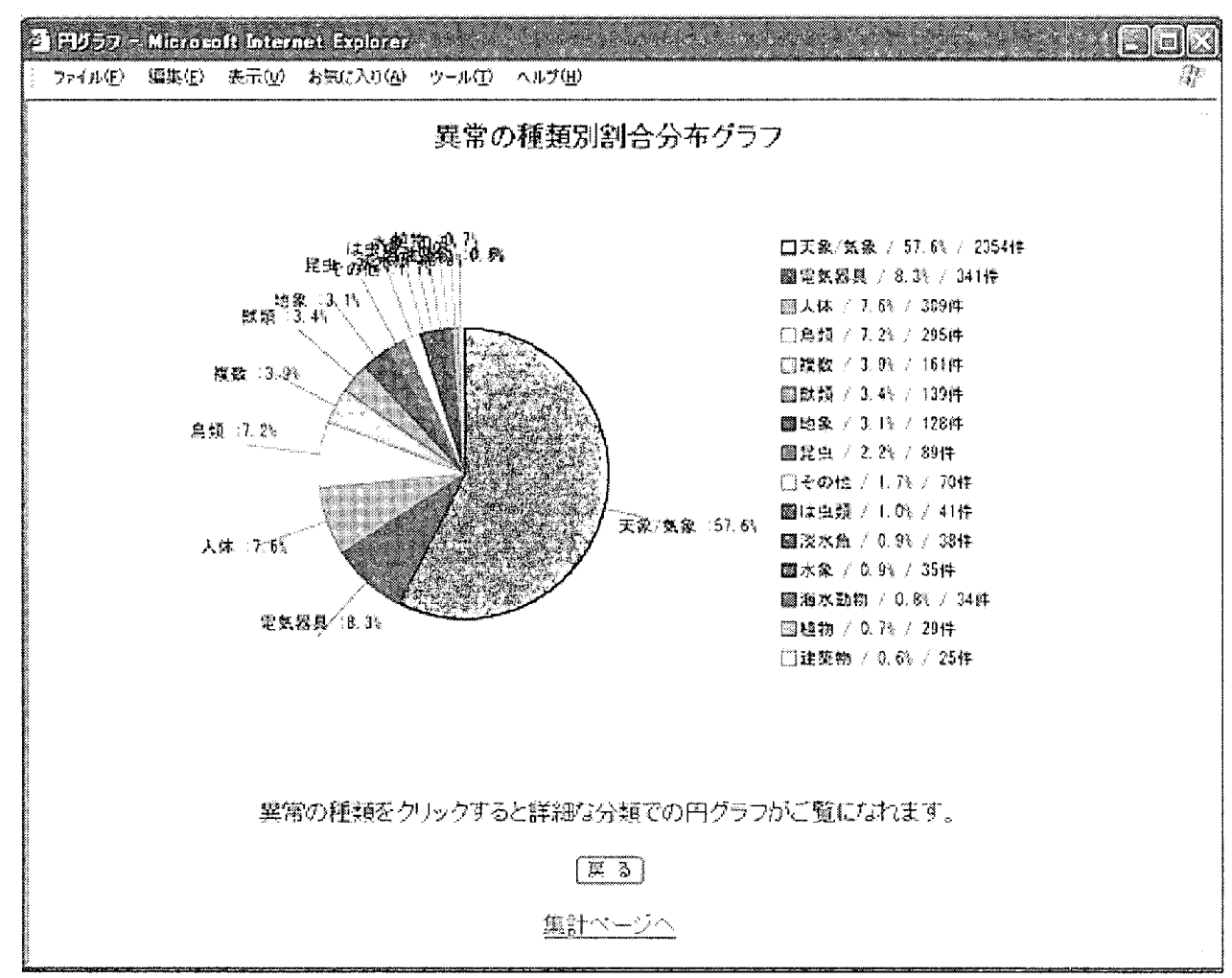

図 3 異常の種類别割合分布グラフ

(http://www1.pisco.ous.ac.jp/maspa/view/circle/graph.html)

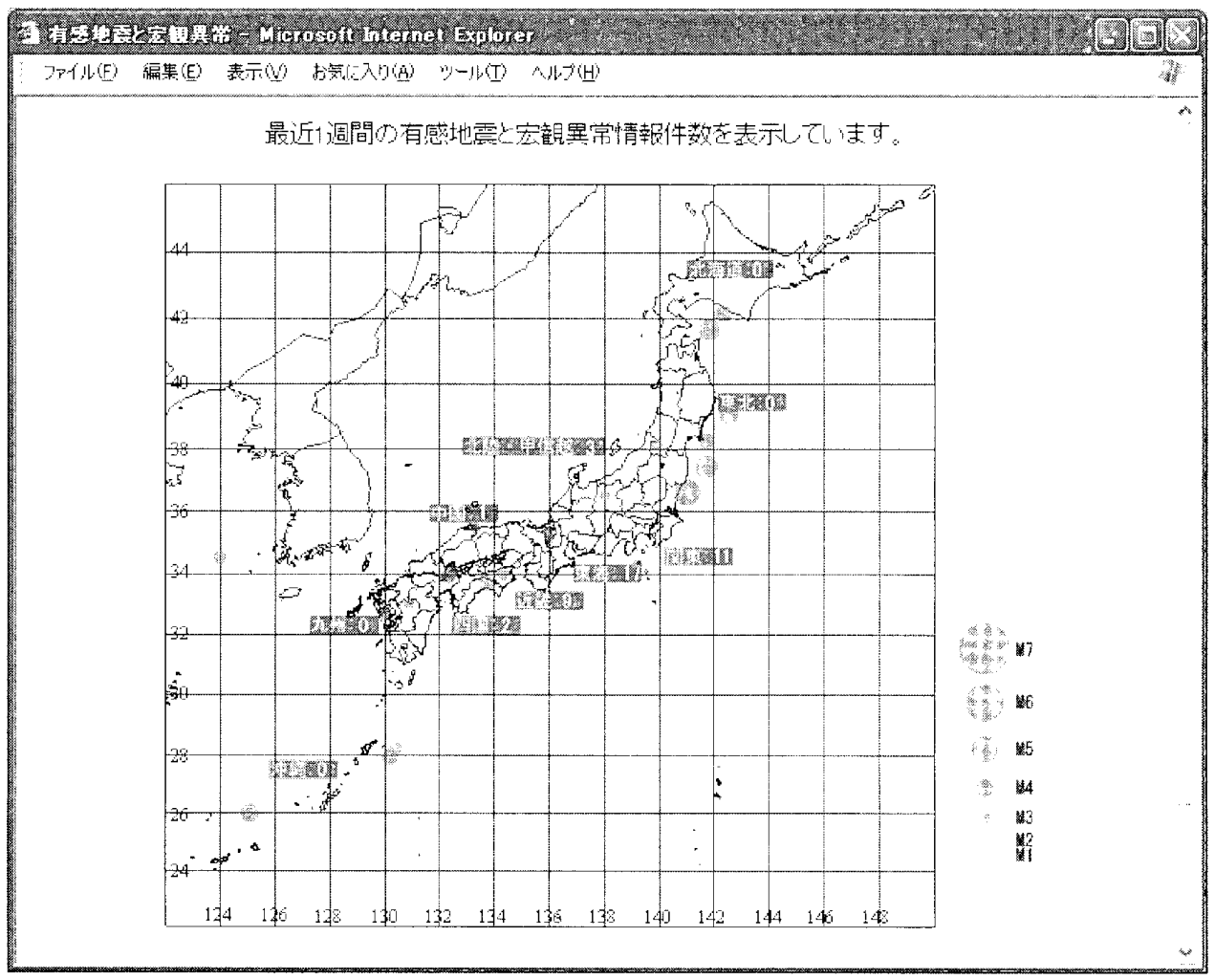

図 4 有感地震と宏観異常情報の地図上表示

(ht.tp://www1.pisco.ous.ac.jp/map/japan.asp) 


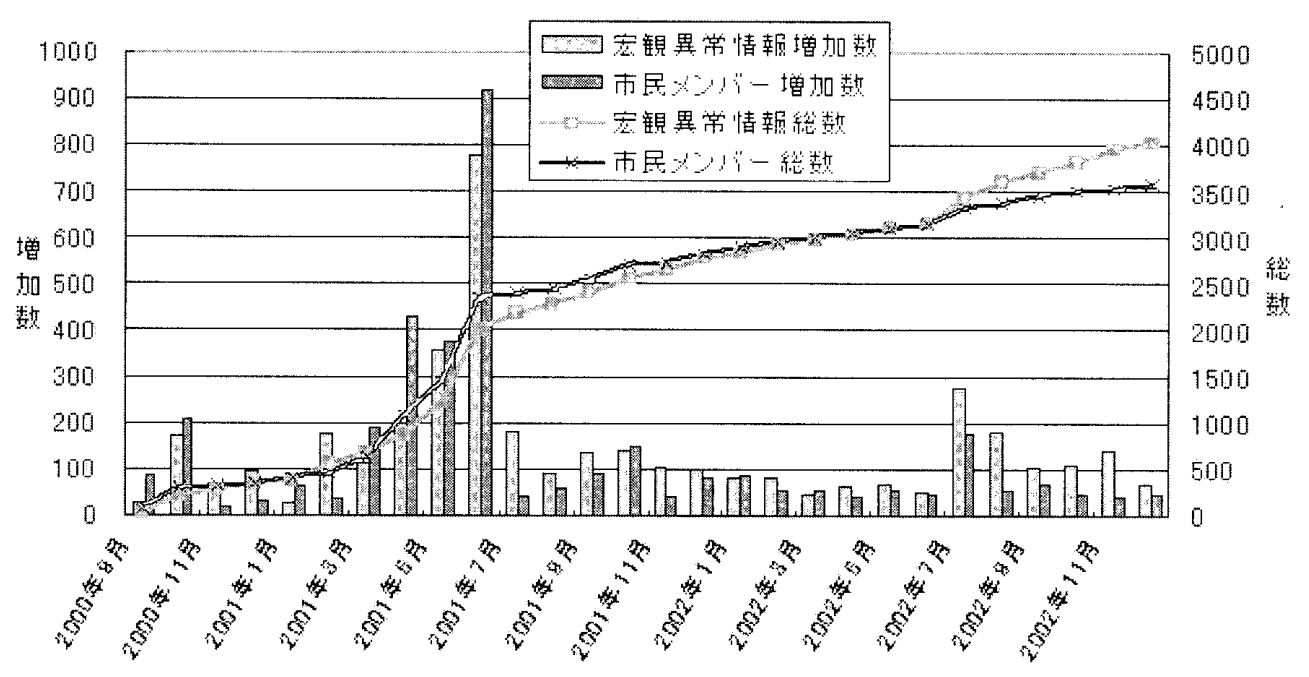

図 5 㾀锶異常情報とわ比メンバーの推移グラフ

\section{4 宏観異常情報システムの運用結果}

宏推異常情竍システムは, 2002 䠊 12 月現在 で約 2 年 3 ケ月間連用して抢り，この間の連 用結果を簡単に紹介寸る。図 5 は, 宏観異常 情報件数と市民メンバー数の推移グラフであ る。一ヶ月単位の情報件数と登録者数を棒グ ラフで表示し，それぞれの総数を折机線グラ フで表している。2002 年 12 月末現在, 市民メ ンバー登録者数は 3573 人, 宏観異常情郝件数 は3951件である。最近三ヶ月では，月平均約 100 件の宏観異常情報が寄也られ，市民メン バーは月平均約 50 人增加している。宏観異常 情報と市武メンバーが共に急増したのは, 2001 年 4 月から 6 月の間である。このときは，3月 24日の芸予地震 (M6.7)の影響により地震へ の関心が高まっていた。そこに，本研究室で 地震危険予知の方法の一つとして使用してい る大気イオン濃度が急上昇したことが重なっ た為，宏観孯常情報と市民メンバーの増加に 慗がったと考えている。このとき，宏観異常 情報システム老含む e-PISCO や i-PISCOサ イトへのアクセス数もこれまでの10倍まで急 増した。今後も，2000 年 10 月の鳥取県西部 地震や, 2001 年 3 月の芸予地震などのような 規慔の大きな地震が内陸で発生した場合，㗨 観異常情報システム含吉 c-PISCO サイト へのアクセス数が急增すると予想される。

\section{5 結論と今後の課題}

2000 年 9 月 1.5 日から 2002 年 12 月までの 間，システムのソフトとハード，セキュリティ， 宏観異常情辩の表現方法の三点に扔ける開発 と强化在行った。この結果，システムはソフ トとハードの搪張により安走して動作し, SSL の利用やその他のセキュリティ対策により交 全性が问上，宏観異常情報は表現方法が多様 化した。これにより，PISCOが目指す住民参 加型の地震危険予知への, システム面での総 合的な体制が整ってきたと考えている。

今後，丢観珙常情報を地震危険予知入活用 させるためには，もっと多くの一般市民の方名 に宏観異常現象老知ってもらい，コらには大 気イオン濃度や地震活動情報との連携による 精度の向上が必要だと考えられる。広観異常 現象は不定偶発的なものである。この現象を 観察するため，市民メンバーが 365 日休みな く注意を払い続けることは非常に困難である。 そのため, 大気イオン濃度や地震活動などの 計測可能な情報と組み合わせることが必要が ある。これは, 機器計測で異常が発生した地 域で, 地震発生の直前に向けて増える傾问に ある宏観異常現象を観察することにより，地 震の直前予知へ慗がると考えているからであ る。そして, 宏観異常現象を見つけるセンサー となるのは人間である。そのため, より多く 
の人が市民メンバー登録し，信頼性を向上さ せることが必要だと考えている。

\section{参考文献}

[1]力武常次：「地震前兆現象予知のための データベース」, 東京大学出版, p.232, 1986.

[2] 弘原海清; 原口竜一; 杉田昌子：「台湾集 集地震と兵庫目南部地震の直前宏観異常 現象」, 地球惑星科学関連学会合同大会, 2000 .

[3] 原口滰一; 和佐好智; 西橋政秀; 弘原海 清:「宏観異常情報システムMASPAの概 要」, 情報地質学会, Vol.12, no.2, pp.62$63,2001$.
[4] 内田陽一；和佐好智；川合桂史；原口童 一; 弘原海清:「モバイルサイト i-PISCO の機能強化」，情報地質，Vol.13，no.2, pp.120-121， 2002.

[5] 井田佳伸; 和佐好智; 内田陽一; 弘原海 清:SVG(Scalable Vector Graphics)を用 いた宏観異常と有感地震の地図上表示, 情 報地質, Vol.13, no.2, pp.58-59, 2002.

[6] 弘原海清:「阪神淡路大震災前兆現象 1519 !」, 東京出版, p.264, 1995.

[7] 弘原海清:「大地震の前兆現象」, 河出書 房新社, p.208, 1998.

(2003 年 1 月 15 日受付) (2003 年 2 月 26 日採録) 